University of Nebraska - Lincoln DigitalCommons@University of Nebraska - Lincoln

Biological Systems Engineering: Papers and

Publications

Biological Systems Engineering

$5-2010$

\title{
Optimization and economic evaluation of industrial gas production and combined heat and power generation from gasification of corn stover and distillers grains
}

\author{
Ajay Kumar \\ Oklahoma State University, ajay.kumar@okstate.edu \\ Yasar Demirel \\ University of Nebraska-Lincoln, ydemirel2@unl.edu \\ David D. Jones \\ University of Nebraska-Lincoln, david.jones@unl.edu \\ Milford Hanna \\ University of Nebraska-Lincoln, mhanna1@unl.edu
}

Follow this and additional works at: https:// digitalcommons.unl.edu/biosysengfacpub

Kumar, Ajay; Demirel, Yasar; Jones, David D.; and Hanna, Milford, "Optimization and economic evaluation of industrial gas production and combined heat and power generation from gasification of corn stover and distillers grains" (2010). Biological Systems Engineering: Papers and Publications. 328.

https://digitalcommons.unl.edu/biosysengfacpub/328

This Article is brought to you for free and open access by the Biological Systems Engineering at DigitalCommons@University of Nebraska - Lincoln. It has been accepted for inclusion in Biological Systems Engineering: Papers and Publications by an authorized administrator of DigitalCommons@University of Nebraska - Lincoln. 


\title{
Optimization and economic evaluation of industrial gas production and combined heat and power generation from gasification of corn stover and distillers grains
}

\author{
Ajay Kumar, ${ }^{1}$ Yasar Demirel, ${ }^{2}$ David D. Jones, ${ }^{3}$ and Milford A. Hanna ${ }^{3,4}$ \\ 1. Department of Biosystems and Agricultural Engineering, Oklahoma State University, Stillwater, OK 74078, USA \\ 2. Department of Chemical and Biomolecular Engineering, University of Nebraska-Lincoln, Lincoln, NE 68588, USA \\ 3. Department of Biological Systems Engineering, University of Nebraska-Lincoln, Lincoln, NE 68583, USA \\ 4. Industrial Agricultural Products Center, University of Nebraska-Lincoln, Lincoln, NE 68583, USA \\ Corresponding author - M. A. Hanna, 211 L.W. Chase Hall, Lincoln, NE 68583-0730, USA; \\ tel 402 472-1634, fax 402 472-6338, email mhanna1@unl.edu
}

\begin{abstract}
Thermochemical gasification is one of the most promising technologies for converting biomass into power, fuels and chemicals. The objectives of this study were to maximize the net energy efficiency for biomass gasification, and to estimate the cost of producing industrial gas and combined heat and power (CHP) at a feedrate of $2000 \mathrm{~kg} / \mathrm{h}$. Aspen Plusbased model for gasification was combined with a CHP generation model, and optimized using corn stover and dried distillers grains with solubles (DDGS) as the biomass feedstocks. The cold gas efficiencies for gas production were $57 \%$ and $52 \%$, respectively, for corn stover and DDGS. The selling price of gas was estimated to be $\$ 11.49$ and $\$ 13.08 / \mathrm{GJ}$, respectively, for corn stover and DDGS. For CHP generation, the electrical and net efficiencies were as high as $37 \%$ and $88 \%$, respectively, for corn stover and $34 \%$ and $78 \%$, respectively, for DDGS. The selling price of electricity was estimated to be $\$ 0.1351$ and $\$ 0.1287 / \mathrm{kW}$ h for corn stover and DDGS, respectively. Overall, high net energy efficiencies for gas and CHP production from biomass gasification can be achieved with optimized processing conditions. However, the economical feasibility of these conversion processes will depend on the relative local prices of fossil fuels.
\end{abstract}

Keywords: Biomass thermochemical gasification, Aspen Plus model, Combined heat and power generation, Industrial gas, Economics

\section{Introduction}

Thermochemical gasification converts feedstock primarily into gas containing $\mathrm{CO}, \mathrm{H}_{2}, \mathrm{CH}_{4}, \mathrm{CO}_{2}$, and/or $\mathrm{N}_{2}$ at high temperature and in presence of catalysts and oxidizing agents. Versatility, in terms of the feedstock, and many potential usages of products gases for producing energy and a wide range of chemicals and fuels provide enormous opportunities for biomass thermochemical gasification.

Combined heat and power (CHP) generation through biomass gasification is a direct route to extract energy from renewable resources efficiently. Use of biomass reduces the $\mathrm{CO}_{2}$ emission as biomass production consumes $\mathrm{CO}_{2}$ and completes the recycling of $\mathrm{CO}_{2}$ in a shorter cycle. Since biomass is locally available, it can be used to produce heat and electricity in developing and underdeveloped countries where infrastructure for electricity is not available. However, for the rural applications of biomass gasification, the cost of production and technical expertise needed for operation must be reduced (Wu et al., 2002; Siemens, 2001; Abe et al., 2007). The use of biomass also promotes rural economies by creating new markets for these agricultural byproducts. In developed countries, it can reduce the consumption of fossil fuels for CHP generation. The byproducts from bioprocessing facilities such as rice husk, distillers grains and food processing wastes, can be used to displace the demands for electricity and natural gas. Since these byproducts are localized at the facilities, reduction in transportation cost may improve its financial attractiveness. At the same time, the use of byproducts for energy and fuel production will decrease the landfill requirements (Maniatis and Millich, 1998; Prasertsan et al., 2001; Bakos et al., 2008; Morey et al., 2006; Hussain et al., 2003; De Kam et al., 2007; Kinoshita et al., 1997).

Combustion and gasification are two processes for CHP generation from biomass. Combustion of biomass to produce heat and electricity is the most conventional and direct use of biomass for producing heat. Gasification of biomass and subsequent combustion to generate CHP has some advantages. First, the conversion of biomass to gas enables the removal of the nitrogen and sulfur containing compounds from the product gas which generate $\mathrm{SO}_{x}$ and $\mathrm{NO}_{x}$ during combustion. Hence, gasifi- 
cation can reduce harmful emissions. Second, a combined cycle with gas and steam turbines, for producing power from product gas, increases the net efficiency of the process as compared to using a steam turbine for combustion (Rentizelas et al., 2009; Faaij et al., 1997; Stiegel and Maxwell, 2001). Third, combustion of a gaseous fuel is easier to control and mix with the oxygen as compared to a solid fuel (e.g., biomass). However, additional operations for gasification increase the capital and operating costs of CHP generation by gasification as compared to direct combustion (Kinoshita et al., 1997). In this study, we have estimated the cost of producing units of heat and power, and gas from biomass.

Corn stover and distillers grains were used as the biomass feedstocks in our study. It is estimated that $204 \mathrm{Mt} \mathrm{year}^{-1}$ (dry basis) of corn stover is available annually in the US (Kadam and McMillan, 2003). Perlack et al. (2005) estimated that annually, 998 million dry tons of agricultural residue and 368 million dry tons of forestry residue are available in US. Dried distillers grains with solubles (DDGS) are the unfermented portion of the corn during conversion of corn to ethanol process. Since, distillers grains are the byproduct of the process, they are available at the site of the ethanol processing facility and can supply the heat and electricity needs of the plant, displacing the use of fossil fuels (Tiffany et al., 2007).

We developed and validated an Aspen Plus-based gasification model in our previous study. Here, the gasification model was integrated with a CHP generation model. Therefore, the objectives of this study were to simulate CHP generation from biomass (corn stover and DDGS) using our previously developed gasifier model, to optimize the operating conditions to obtain maximum energy efficiency, and to conduct an economic evaluation of the optimized process to determine the cost of production of product gas or CHP by biomass gasification.

\section{Methods}

Corn stover and DDGS were used a the biomass feedstocks. The properties of corn stover and DDGS were described in Kumar et al. (2008) and Wang et al. (2009), respectively. The moisture contents of the corn stover and distillers grains were $6.2 \%$ and $12.16 \%$, respectively, on a wet basis.

\subsection{Aspen Plus model}

The Aspen Plus-based model for gasification was developed and validated previously at a biomass feedrate of approximately $1 \mathrm{~kg} / \mathrm{h}$. The model has been described in detail by $\mathrm{Ku}-$ mar et al. (2009b). The underlying assumption of this gasifier model was that tar and char yields are known. The gasifier was represented by a combination of two reactors (called DECOMP and G-REACTR) and a separator (called C-SEP), shown in Figure 1 . The purpose of the DECOMP rector was to breakdown the biomass into conventional compounds so the reaction, with oxidizing agents, could be simulated in a subsequent Gibbs reactor (G-REACTR). The input to the DECOMP reactor was only biomass. Knowing yields of tar, balancing the mass of each element and ash of biomass, and assuming a ratio of $\mathrm{CO}$ and $\mathrm{CO}_{2}$, mass yields of DECOMP products were calculated. After separating known amount of char from the DECOMP products by a separator (called C-SEP), a heterogeneous reaction took place in a Gibbs reactor (called G-REACTR, shown in Figure 1) to determine final product composition by minimization of the products' Gibbs free energy.

Yields of char and tar were assumed to be known. For corn stover, mass yields of $\mathrm{H}_{2} \mathrm{O}$, ash, carbon, $\mathrm{H}_{2}, \mathrm{NH}_{3}, \mathrm{O}_{2}, \mathrm{~S}, \mathrm{CO}, \mathrm{CH}_{4}$, $\mathrm{CO}_{2}$ and tar from the DECOMP reactor were provided as 0.05 , $0.08,0.16,0.004,0.009,0,0.003,0.088,0.168,0.415$ and $0.023 \mathrm{~kg} / \mathrm{kg}$ corn stover, respectively. For DDGS, mass yields of $\mathrm{H}_{2} \mathrm{O}$, ash, carbon, $\mathrm{H}_{2}, \mathrm{NH}_{3}, \mathrm{O}_{2}, \mathrm{~S}, \mathrm{CO}, \mathrm{CH}_{4}, \mathrm{CO}_{2}$ and tar from the
DECOMP reactor were provided as $0.1216,0.051,0.16,0.012$, $0.053,0,0.008,0.073,0.154,0.345$ and $0.022 \mathrm{~kg} / \mathrm{kg}$ DDGS, respectively. These mass yields correspond to mass yields for the most efficient experimental conditions of biomass.

The components for CHP generation were added to the gasifier model and biomass feed rate was increased to $2000 \mathrm{~kg} / \mathrm{h}$. The main components added to the CHP model were a gas turbine, steam turbine, air compressor, combustor, boiler, and condenser. The parameters for gasifier and turbines (Table 1) are similar to the parameters described by Sudiro et al. (2008), Xinag and Wang (2008), Faaij et al. (1997), and Ståhl and Neergaard (1998).

Two scenarios were evaluated in this study. One scenario was to produce industrial gas from the biomass at optimum gasification conditions. The second scenario was to convert the product gas at the optimum gasification conditions to combined heat and power (CHP) with a combined cycle using gas and steam turbines.

For the first scenario, gasification temperature, equivalence ratio and steam to biomass ratio were varied from 700 to $850{ }^{\circ} \mathrm{C}$, 0.05 to $0.25{ }^{\circ} \mathrm{C}$, and o to $3.0^{\circ} \mathrm{C}$, respectively. The gasification model was optimized to achieve maximal energy efficiency by varying the previously described operating conditions. The total energy input to the system was the sum of the energy in the biomass, and energy needed to obtain air at $400{ }^{\circ} \mathrm{C}$ and steam at $400{ }^{\circ} \mathrm{C}$ at $1 \mathrm{~atm}$. The total energy output from the system was the sum of the sensible and chemical energy contents of the product gas. For energy evaluations, heat losses for operations were assumed to be negligible because the objective was to evaluate maximal theoretical efficiency. Depending on the heat loss for specific equipment, the factor for heat loss needs to be incorporated for determining energy efficiency for a particular system. It should be noted that heat is required to breakdown biomass into gaseous compounds. In case of gasification, supplying a limited quantity of oxidizing agent generated heat from oxidation reactions which provided the heat for the endothermic reactions to take place.

For the second scenario, the product gas from the optimized gasification conditions was supplied to the CHP generation system (Figure 1). The CHP system generated electricity using gas and steam turbines, and the residual sensible heat was recovered using a heat exchanger. The properties of gas and steam turbines are given in Table 1. The total energy input, in this scenario, was the sum of the energy contents of the biomass, air and steam and the energy supplied to the air compressor. The total energy output from the system was the sum of the electrical energy generated from the gas and steam turbines, and the sensible energy of the hot water produced by the condensing waste steam and by cooling the product gas.

The cold gas efficiency of this system was defined as the percentage of total energy input available in the form of chemical energy of the producer gas at standard temperature and pressure. The net gas efficiency was defined as the percentage of total energy input available in the form of chemical and heat energies of producer gas and electricity produced in case of CHP system.

\subsection{Economical evaluation}

The economics for producing either gas or combined heat and electricity were evaluated at a biomass feedrate of a $2000 \mathrm{~kg} / \mathrm{h}$. The economic evaluations were performed based on the empirical estimation of capital cost with an Excel-based software called CAPCOST version 2.0 from Turton et al. (2002). Chemical engineering plant cost index (CEPCI) of 525.4 for year 2007 was used for the estimation of capital costs (Chemical Engineering, 2009).

The major equipment for gas production was a steam boiler, an air-heater, a cooler and a gasifier. The additional major equipments for the CHP generation system were an air compressor, two heat exchangers, a gas turbine and a steam turbine. The grass 


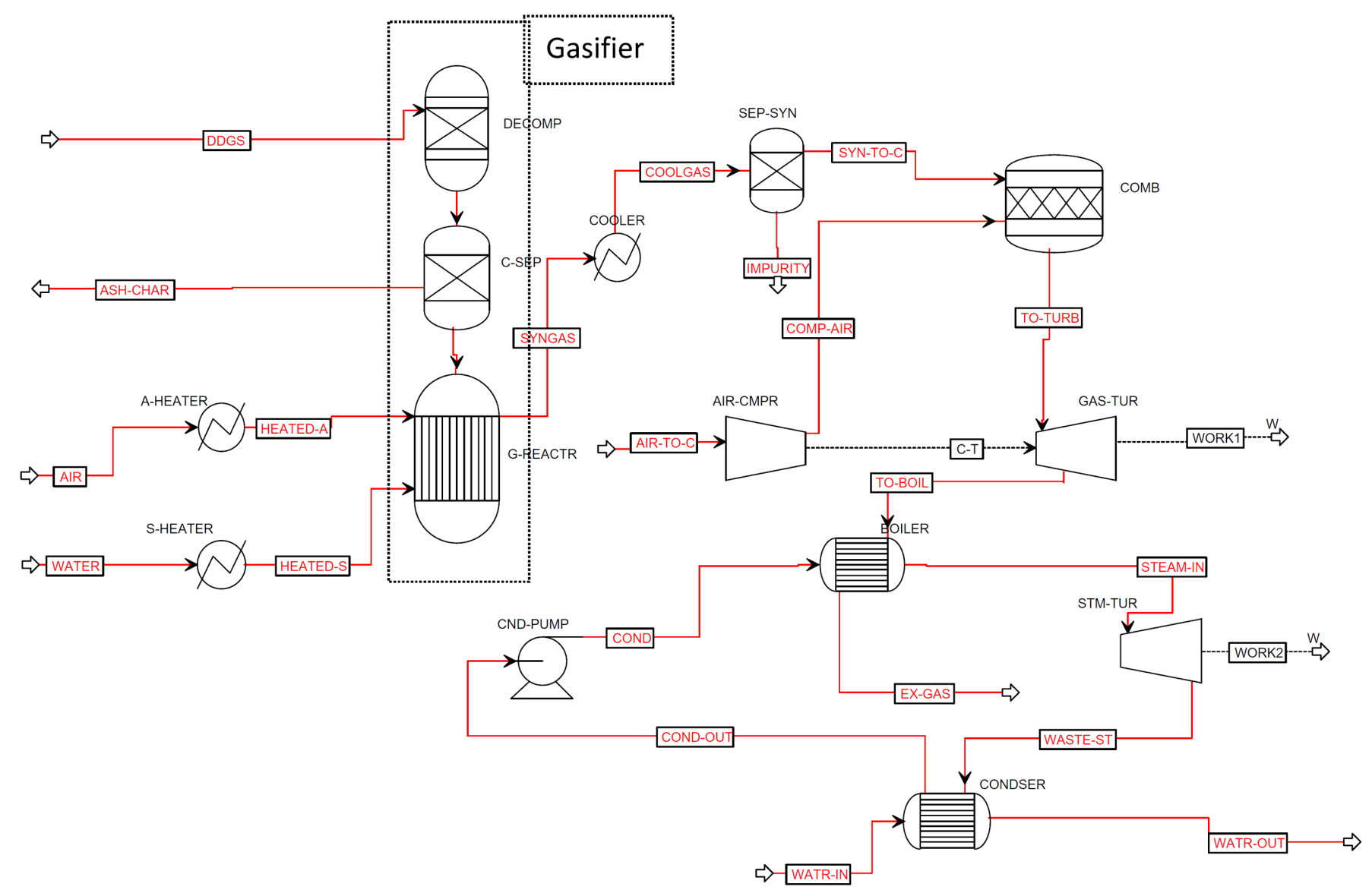

Figure 1. Process flow diagram of CHP generation from biomass gasification.

Table I. Parameters of the main equipments for CHP generation.

\begin{tabular}{ll}
\hline Equipment & Conditions \\
\hline Gasifier & $\begin{array}{l}\text { Atmospheric pressure, temperature } 850{ }^{\circ} \mathrm{C} \text {, cold } \\
\text { gas efficiency of } 58 \% \text { for corn stover and } 52 \% \text { for }\end{array}$ \\
& DDGS gasification \\
Gas turbine & $\begin{array}{l}\text { Isentropic/mechanic efficiency } 92 / 99 \% \text {, discharge } \\
\text { pressure of I.4 bar } \\
\text { Steam turbine }\end{array}$ \\
& $\begin{array}{l}40 \text { bar, } 450{ }^{\circ} \mathrm{C} \text {, isentropic/mechanic efficiency } \\
88 / 97.5 \%, \text { discharge pressure I.4 bar }\end{array}$ \\
\hline
\end{tabular}

root values of the capital costs were considered for this analysis. The grass root value was the cost associated with building the facility on essentially undeveloped land, which includes costs for contingency, fees and auxiliary facilities (Turton et al., 2002). A modified accelerated cost recovery system (MACRS) method for 7 years was applied for determining depreciation of equipment. Water and electricity, as utilities, were estimated to cost $\$ 0.544 /$ $\mathrm{m}^{3}$ and $\$ 0.12 / \mathrm{kW} \mathrm{h}$, respectively. The cost for water was adopted from Wei et al. (2008). The high temperature heat needed for producing hot air and superheated steam was assumed to cost \$7.5/GJ. Costs of corn stover (including the cost of delivering and grinding) and DDGS (including the cost of delivering), as raw materials, were estimated to be $\$ 60.15 /$ dry Mg (Sokhansanj and Turhollow, 2004), and $\$ 132 / \mathrm{Mg}$ with $10 \%$ moisture, wet basis (National Weekly Ethanol Summary, 2009), respectively.

The periods for construction and operation were assumed to be 1 and 15 years, respectively. The plant was assumed to operate
350 days per year. Rate of taxation and interest were set as $42 \%$ and $6 \%$, respectively. The cost of land and operating labor were assumed to cost $\$ 150,000$ and $\$ 250,000$ each, for the productions of gas and CHP, respectively. Working capital was assumed to be $15 \%$ of the total grass root value. The salvage value was assumed to be $10 \%$ of the capital cost. Since the cost of the main product (electricity or gas) was to be evaluated in this study, the revenue from process heat was assumed to be $\$ 6 / \mathrm{GJ}$, which is comparable to the price of natural gas.

Three criteria were satisfied to determine the selling price of a unit of electricity or gas. The net present value of the project should be close to or above zero; the payback period should be less than the project life (15 years); and the rate of return should be equal to or higher than the interest rate (6\%). For estimating capital costs on per unit basis, the total capital cost was divided by the units of power produced.

\section{Results and discussion}

The technical and economical assessments of producing either industrial gas or CHP were performed in the following sequence. The operating conditions of the gasification were optimized using our previously developed model to achieve maximal energy efficiency. The economical evaluation was performed subsequently on the optimized model condition to estimate the cost of producing a unit amount of product gas. The CHP generation system was then added to the gasification model. The operating conditions of turbines were varied to obtain maximal electric power from the integrated model. The economical analyses were performed on the optimized and integrated model to estimate the cost of producing a unit amount of electricity. 


\subsection{Optimization of operating condition for maximal energy efficiency}

It was observed that with increasing the temperature of the gasifier from 700 to $850{ }^{\circ} \mathrm{C}$, the net energy efficiency increased from $81 \%$ to $86 \%$ for corn stover and $77 \%$ to $82 \%$ for DDGS, when heat loss were not accounted for. Hence, the gasifier temperature of $850{ }^{\circ} \mathrm{C}$ was selected for further technical and economical analyses. However, it should be mentioned that the model assumed that the gasification reactor maintained a constant temperature of $850{ }^{\circ} \mathrm{C}$. The variable temperature along gasifier may affect the composition of the product gas (Kumar et al., 2009a). Ståhl et al. (2004) reported that, at the scale of $6 \mathrm{MW}_{\mathrm{e}}$, combustion of char was able to maintain the temperature of biomass gasifier. The air flowrate also may affect gasification temperature. The air and steam flow rates affected the gas composition and overall energy efficiency (Table 2 and Figure 2; Kumar et al., 2009a). The desired gas composition will vary depending on the utilization of the product gas. So, the corresponding optimized gasification condition is dependent on how the product gas is utilized. For example, for corn stover gasification, CO was maximal for condition \#1 with zero steam flow and an equivalence ratio (ER) of 0.056 (air flow of $0.64 \mathrm{~kg} / \mathrm{kg}$ corn stover). Hydrogen yield increased with increasing steam to biomass ratio. Net energy efficiency was maximal (cold gas efficiency of 58\%) at condition \#4. With an assumption of $5 \%$ heat loss from process heat, the net energy efficiency for gas production was 90\%. In this study, since the objective of this study was to perform economic evaluation at the maximal net energy efficiency, condition \#4 was selected as the optimum gasification conditions with an

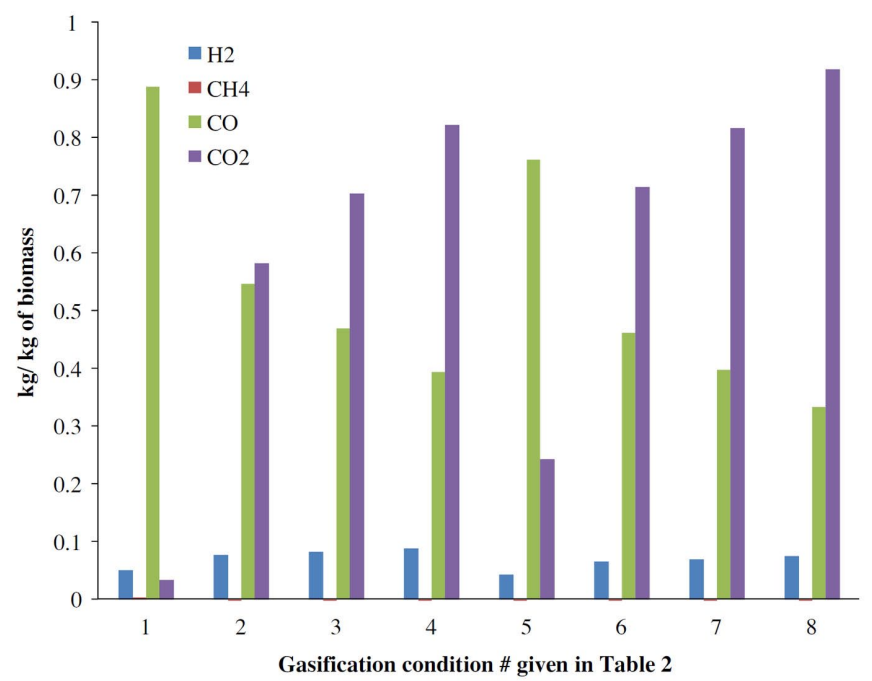

Figure 2. Energy conversion efficiency with varying flowrates of air and steam at $850{ }^{\circ} \mathrm{C}$ for corn stover gasification.
ER of 0.11 and steam to biomass ratio of $1.47 \mathrm{~kg} / \mathrm{kg}$ for corn stover. For DDGS, the net energy efficiency reached $94.2 \%$ at the ER and steam to biomass ratio of 0.073 and 2.95, respectively. The net efficiency of this system was comparable to the $83 \%$ net efficiency reported at the scale of $6 \mathrm{MW}_{\mathrm{e}}$ by Ståhl et al. (2004), $81 \%$ net efficiency by Rentizelas et al. (2009), 93\% fuel to gas efficiency at the scale of $75 \mathrm{~kW}$ input by Ahrenfeldt et al. (2006). The optimum operating conditions will change with incorporating factors for heat losses for particular system. For CHP generation from corn stover, optimum flowrates of air to compressor and steam to steam turbine were $7676 \mathrm{~kg} / \mathrm{h}$ and $7580 \mathrm{~kg} / \mathrm{h}$, respectively, with a total electricity generation of $4.6 \mathrm{~kW}$ from both turbines. For CHP generation from DDGS, optimum flowrates of air to compressor and steam to steam turbine were $7944 \mathrm{~kg} / \mathrm{h}$ and $10,810 \mathrm{~kg} / \mathrm{h}$, respectively, with a total electricity generation of $6.38 \mathrm{~kW}$ from both turbines.

\subsection{Energy balance at the optimized condition}

Since it was assumed that partial combustion of the biomass would maintain the gasification temperature, the energy flow during the gasification reactions was not taken into consideration for energy balance. As expected, with increasing air and steam flowrates, the energy required by the heaters and boilers increased. However, for corn stover gasification, supplying steam up to $1.47 \mathrm{~kg}$ steam $/ \mathrm{kg}$ biomass also resulted in increased total energy content of the product gas. The sensible heat of the product gas ranged from $11 \%$ to $40 \%$ of the total energy content in product gas (Table 2). Hence, to maximize the net energy efficiency, the sensible heat of the product gas must be recovered effectively. For gas production at the optimized conditions, the energy input to the system from biomass, hot air and superheated steam were $77 \%, 1.1 \%$, and $21.9 \%$, respectively, of total energy input. The sensible and chemical energy contents of the product gas were $36 \%$ and $64 \%$ of the total energy of the product gas, respectively (Table 2). For DDGS gasification, supplying steam of $2.95 \mathrm{~kg} / \mathrm{kg}$ of biomass resulted in increased net efficiency. The optimum steam to biomass ratio will change if the sensible heat from unreacted steam cannot be recovered. At the optimum condition of gas production, $44.7 \%$ of total output energy was available as sensible energy of product gas. The energy supplied by the hot air, superheated steam and biomass were $0.65 \%, 29 \%$ and $70 \%$ of total energy input, respectively.

For CHP production, additional energy was required by the air compressor. Since the compressor was driven by the gas turbine, the energy required by the compressor was subtracted from the electrical energy of the gas turbine. For corn stover gasification, the gas and steam turbines generated electrical power of 3.27 and $1.36 \mathrm{~kW}$ at the optimum conditions. The total process heat from condensate and cooling of product gas was $6.12 \mathrm{~kW}$. The electrical and thermal efficiencies of the system were $37 \%$ and $49 \%$, respectively. For DDGS gasification, gas and steam turbines generated 4.4 and $1.9 \mathrm{~kW}$ of electricity. In this

Table 2. Operating conditions and energy balance for the corn stover gasification.

\begin{tabular}{|c|c|c|c|c|c|c|}
\hline $\begin{array}{c}\text { Condition } \\
\#\end{array}$ & $\begin{array}{l}\text { Air } \\
(\mathrm{kg} / \mathrm{kg} \text { biomass })\end{array}$ & $\begin{array}{l}\text { Steam } \\
\text { (kg/kg biomass) }\end{array}$ & $\begin{array}{l}\text { QAir* } \\
(\mathrm{kW})\end{array}$ & $\begin{array}{l}\text { QSteam* } \\
(\mathrm{kW})\end{array}$ & $\begin{array}{l}\text { QCooler* } \\
(\mathrm{kW})\end{array}$ & $\begin{array}{l}\text { Qgas* } \\
\text { (kW) }\end{array}$ \\
\hline 1 & 0.64 & 0.00 & 136 & 0 & 1080 & 7578 \\
\hline 2 & 0.64 & 0.74 & 136 & 1367 & 2601 & 7337 \\
\hline 4 & 0.64 & 1.47 & 136 & 2734 & 4270 & 7231 \\
\hline 5 & 1.27 & 0.00 & 272 & 0 & 1489 & 6240 \\
\hline 6 & 1.27 & 0.74 & 272 & 1367 & 3055 & 6030 \\
\hline
\end{tabular}

QAir* and QSteam* are energy required to generate air, and steam at $400{ }^{\circ} \mathrm{C}$, respectively.

QCooler* and Qgas* are energy available in the product gas as sensible and chemical energy, respectively. 
case, the electrical and thermal efficiencies were $34 \%$ and $44 \%$, respectively. The results were similar to the 35.4-40.3\% electrical efficiency reported by Faaij et al. (1997), 32\% electrical efficiency reported by Ståhl et al. (2004), and 35-40\% electrical efficiency reported by Craig and Mann (1996).

\subsection{Economical analysis of the optimized conditions}

With the optimized conditions, the product gas flowrate was $72.3 \mathrm{~N} \mathrm{~m}^{3} / \mathrm{s}$ with energy content (HHV) of $6.00 \mathrm{MJ} / \mathrm{Nm}^{3}$ for corn stover. For DDGS, product gas flow rate was $64.4 \mathrm{~N} \mathrm{~m}^{3} / \mathrm{s}$ with an energy content of $8.78 \mathrm{MJ} / \mathrm{Nm}^{3}$. The energy content of the product gas from DDGS gasification was higher because of the higher energy content in the DDGS as compared to the corn stover. Since the product gas can be used as chemical feedstocks to produce valuable fuels and chemicals such as hydrogen, ammonia, methanol, the price of product at the commercial scale are dependent on the composition of the product gas. However, additional process operations are needed to provide the acceptable gas composition for use as chemical feedstocks. For simplicity, we estimated the selling price of the product gas based on its energy content rather than its composition.

For gas production, the total grass root capital cost for gas production for both feedstocks was estimated to be $\$ 3.17$ million (Table 3). For corn stover, with a selling price of product gas was $\$ 11.49 /$ GJ with a discounted payback period and rate of return of 12.9 years and 6\%, respectively. For DDGS, the selling price of product gas was $\$ 13.08 / \mathrm{GJ}$ with a discounted payback period and rate of return of 12.9 years and 6\%, respectively. Seventy-six and seventy-three percent of total revenues were generated from product gas for corn stover and DDGS, respectively. The selling price of gas was higher from DDGS as compared to corn stover gasification. At the scale of $60 \mathrm{~N} \mathrm{~m}^{3} \mathrm{~h}^{-1}$, Wei et al. (2008) estimated the cost of producing syngas to be $\$ 0.009 \mathrm{MJ}^{-1}$. Their estimation was based on the cost of wood feedstock at $\$ 25 /$ ton.

For CHP generation, the total grass root capital cost was estimated to be $\$ 12.4$ million for both feedstocks. The capital cost for the part of CHP generation, such as turbines and boiler, was approximately three times more than the capital costs for gasification only. The revenue, in this scenario, was generated from the electricity and process heat. For corn stover, the cost of electricity (coE) was $\$ 0.1351 / \mathrm{kW} \mathrm{h}$ with discounted rate of return at $6 \%$ and payback period of 12.7 years. For DDGS, the coE was estimated to be $\$ 0.1287 / \mathrm{kW}$ h with discounted rate of return at $6 \%$ and payback period of 12.7 years. Eighty-two percent of the total revenue generated was from electricity for both feedstocks. The coE for DDGS gasification was lower than that of corn stover gasification. The per unit capital costs were $\$ 2681$ and \$1944/ kW for corn stover and DDGS, respectively.

Although the capital cost for CHP generation was much higher than that of gas production only, the revenue was proportionally higher due to the revenue generated from cost of elec- tricity (Rentizelas et al., 2009). These estimates for coE were closer to the estimates reported in the literature. Brammer and Bridgwater (2002) reported that the coE for the optimum condition was 8.67 Euro c/kW h with feedrate of $2 \mathrm{dt} / \mathrm{h}$ at a cost of 30 Euro/dt. They concluded that drying should be done as far as possible before gasifier, to increase the net energy efficiency and decrease the coE. Kinoshita et al. (1997) reported the capital cost estimate to be from 1400 to $2750 \$ / \mathrm{kW}$ for smaller scale biomass combined heat and power generation systems (less than 20 MW). However, at a scale of more than 50 MW, Craig and Mann (1996) estimated the capital cost and coE to be 1108$1696 \$ / \mathrm{kW} h$ and $0.066-0.082 \$ / \mathrm{kW} \mathrm{h}$, respectively. They also observed that with increase in scale, the capital cost for the CHP generation lowers. However, biomass based gasification system is unlikely to be of such large scale because biomass generally is not available at one centralized location. The comparatively lower capital cost of $1200 \$ / \mathrm{kW}$, reported by Wu et al. (2008) at a scale of 5.5 $\mathrm{MW}_{\mathrm{e}}$, may be because of the use of gas engines as compares the turbines.

The gasification and CHP generation equipment may need to be modified as the particle and energy densities of the biomass and biomass generated gas are lower than those of fossil resources such as coal and natural gas. Hence, the estimated capital cost may change accordingly. Ståhl et al. (2004) observed that after some modification, a gas turbine was suitable for generating electricity from the low energy content product gas (up to $3.9 \mathrm{MJ} / \mathrm{Nm}^{3}$ ) from biomass gasifier. The energy contents of the product gases, at our optimum conditions, were 5.86 and $8.78 \mathrm{MJ} / \mathrm{Nm}^{3}$ for corn stover and DDGS, respectively. This energy content was similar to the $5.8 \mathrm{MJ} / \mathrm{Nm}^{3}$ obtained from dry wood chips by Kramreiter et al. (2008). The production of valuable chemicals from product gas may be more economically attractive than CHP generation. Currently syngas (a mixture of $\mathrm{CO}, \mathrm{CO}_{2}$ and $\mathrm{H}_{2}$ ) is produced from natural gas using an energyintensive steam reforming process. The syngas is then used as a feedstock to produce chemicals such as hydrogen, ammonia and methanol. Hence, based on energy efficiency and economics, product gas from biomass gasifier may be more competitive with syngas to produce fuels and chemicals than with natural gas for CHP generation.

\section{Conclusions}

An Aspen Plus-based model of gasification was optimized to obtain maximum energy efficiency by varying gasification temperature and flowrates of air and steam. Higher temperature increased the efficiency. Assuming that the gasification temperature was maintained at $850^{\circ} \mathrm{C}$ by the air supplied, maximal net energy efficiency was $92 \%$ and $94 \%$ when no heat loss was considered for corn stover and DDGS, respectively. The economical evaluation of optimum model revealed that the minimum selling price of gasifier product gas was $\$ 11.49$ and $\$ 13.08 / \mathrm{GJ}$, for

Table 3. Economical results for gas production and CHP generation from corn stover and DDGS gasification.

\begin{tabular}{|c|c|c|c|c|}
\hline Item & $\begin{array}{l}\text { Gas production } \\
\text { from corn stover }\end{array}$ & $\begin{array}{l}\text { CHP generation } \\
\text { from corn stover }\end{array}$ & $\begin{array}{l}\text { Gas production } \\
\text { from DDGS }\end{array}$ & $\begin{array}{l}\text { CHP generation } \\
\text { from DDGS }\end{array}$ \\
\hline Fixed capital investment $(\$)$ & $3,170,000$ & $12,400,000$ & $3,170,000$ & $12,400,000$ \\
\hline Cost of land $(\$)$ & 150,000 & 250,000 & 150,000 & 250,000 \\
\hline Cost of utility (\$/year) & 664,355 & 664,355 & $1,298,860$ & $1,298,860$ \\
\hline Cost of raw material ( $\$ /$ year) & 889,089 & 889,089 & $1,901,160$ & $1,901,160$ \\
\hline Selling price for heat ( $\$ / G J)$ & 6 & 6 & 6 & 6 \\
\hline Revenue from gas or electricity $(\$)$ & $2,5|2,43|$ & $5,249,770$ & $3,854,530$ & $6,897,290$ \\
\hline Selling price for gas $(\$ / G)$ & 11.49 & & 13.08 & \\
\hline Selling price for electricity $(\$ / k W h)$ & & 0.1351 & & 0.1287 \\
\hline
\end{tabular}


corn stover and DDGS as the biomass feedstocks, respectively. The cost of electricity (selling price) for the combined heat and power generation was estimated to be $\$ 0.1351$ and $\$ 0.1287 /$ $\mathrm{kW}$ h from corn stover and DDGS, respectively. However, these estimates may vary because some equipment may need to be customized for lower mass and energy density of biomass feedstock as well as low energy density of product gas compared to commercially available equipments for CHP generation from coal and natural gas.

Acknowledgments - The authors would like to thank Dr. Noureddini for his help in availing the computing facility. This project was supported in part with Hatch funds through the Agricultural Research Division of the Institute of Agriculture and Natural Resources at the University of Nebraska.

\section{References}

Abe, H., Katayama, A., Sah, B.P., Toriu, T., Samy, S., Pheach, P., Adams, M.A., Grierson, P.F., 2007. Potential for rural electrification based on biomass gasification in Cambodia. Biomass and Bioenergy 31, 656-664.

Ahrenfeldt, J., Henriksen, U., Jensen, T.K., Gobel, B., Wiese, L., Kather, A., Egsgaard, H., 2006. Validation of a continuous combined heat and power (CHP) operation of a two-stage biomass gasifier. Energy and Fuels 20, 2672-2680.

Bakos, G.C., Tsioliaridou, E., Potolias, C., 2008. Technoeconomic assessment and strategic analysis of heat and power generation (CHP) from biomass in Greece. Biomass and Bioenergy 32 (6), $558-567$.

Brammer, J.G., Bridgwater, A.V., 2002. The influence of feedstock drying on the performance and economics of a biomass gasifier-engine CHP system. Biomass and Bioenergy 22, 271-281.

Chemical Engineering, 2009. Economic indicators. Chemical Engineering $116,3$.

Craig, K.R., Mann, M.K., 1996. Cost and Performance Analysis of Biomass-based Integrated Gasification Combined-cycle (BIGCC) Power Systems. National Renewable Energy Laboratory. Golden, Colorado, NREL/TP-430-21657.

De Kam, M.J., Morey, R.V., Tiffany, D.G., 2007. Integrating biomass to produce heat and power at ethanol plants. ASABE Paper No. 076232, ASABE, St. Joseph, Mich.

Faaij, A., Ree, R.V., Waldheim, L., Olsson, E., Oudhuis, A., Wijk, A.V., Ouwens, C.D., Turkenburg, W., 1997. Gasification of biomass waste and residues for electricity production. Biomass and Bioenergy 12 (6), 387-407.

Hussain, Z., Zainal, Z.A., Abdullah, M.Z., 2003. Analysis of biomassresidue-based cogeneration system in palm oil mills. Biomass and Bioenergy 24, 117-124.

Kadam, K.L., McMillan, J.D., 2003. Availability of corn stover as a sustainable feedstock for bioethanol production. Bioresource Technology 88, 17-25.

Kinoshita, C.M., Turn, S.Q., Scott, S.Q., Overend, R.P., Bain, R.L., 1997. Power generation potential of biomass gasification systems. Journal of Energy Engineering 88, 88-99.

Kramreiter, R., Url, M., Kotik, J., Hofbaur, H., 2008. Experimental investigation of a $125 \mathrm{~kW}$ twin-fire fixed bed gasification pilot plant and comparison to the results of a $2 \mathrm{MW}$ combined heat and power plant (CHP). Fuel Processing Technology 89, 90-102.

Kumar, A., Wang, L., Dzenis, Y.A., Jones, D.D., Hanna, M.A., 2008. Thermogravimetric characterization of corn stover as gasification and pyrolysis feedstock. Biomass and Bioenergy 32 (5), 460-467.

Kumar, A., Eskridge, K., Jones, D.D., Hanna, M.A., 2009a. Steam-air fluidized bed gasification of distillers grains: effects of steam to biomass ratio, equivalence ratio and gasification temperature. Bioresource Technology 100 (6), 2062-2068.
Kumar, A., Demirel, Y., Noureddini, H., Jones, D.D., Hanna, M.A., 2009b. Simulation of corn stover and distillers grains gasification with Aspen Plus. Transactions of the ASABE 52 (6), 1989-1995.

Maniatis, K., Millich, E., 1998. Energy from biomass and waste: the contribution of utility scale biomass gasification plants. Biomass and Bioenergy 15 (3), 195- 200.

Morey, R.V., Tiffany, D.G., Hatfield, D.L., 2006. Biomass for electricity and process heat at ethanol plants. Applied Engineering in $\mathrm{Ag}$ riculture 22 (5), 723-728.

National Weekly Ethanol Summary. Reported on April 17, 2009; http://www.ams.usda.gov/mnreports/lswethanol.pdf

Perlack, R.D., Wright, L.L., Turhollow, A.F., Graham, R.L., Stokes, B.J., Erbach, D.C., 2005. Biomass as a Feedstock for a Bioenergy and Bioproducts Industry: The Technical Feasibility of BillionTon Annual Ton Supply, April, DOE/Go-102005- 2135 ORNL/ TM-2005/66.

Prasertsan, S., Krukanont, P., Ngamsritragul, P., Kirirat, P., 2001. Strategy for optimal operation of a biomass-fired cogeneration power plant. Proceedings of the Institution of Mechanical Engineers 215(A), 13-26.

Rentizelas, A., Karellas, S., Kakaras, E., Tatsiopoulos, I., 2009. Comparative technoeconomic analysis of ORC and gasification for bioenergy applications. Biomass and Bioenergy 50, 674-681.

Siemens, R.V., 2001. Identifying a role for biomass gasification in rural electrification in developing countries: the economic perspective. Biomass and Bioenergy 20, 271-285.

Sokhansanj, S., Turhollow, A.F., 2004. Biomass densification - cubing operations and costs for corn stover. Applied Engineering in Agriculture 20 (4), 495-499.

Ståhl, K., Neergaard, M., 1998. IGCC power plant for biomass utilization, Värnamo, Sweden. Biomass and Bioenergy 15 (3), 205-211.

Ståhl, K., Waldheim, L., Morris, M., Johnsson, U., Gårdmark, L., 2004. Biomass IGCC at Värnamo, Sweden - Past and future. In: GCEP Energy Workshop, April 27, 2004. Frances C. Arrilaga Alumni Center, Standford University, CA, USA.

Stiegel, G.J., Maxwell, R.C., 2001. Gasification technologies: the path to clean, affordable energy in the 21st century. Fuel Processing Technology 71, 79-97.

Sudiro, M., Bertucco, A., Ruggeri, F., Fontana, M., 2008. Improving process performances in coal gasification for power and synfuel production. Energy and Fuels 22, 3894-3901.

Tiffany, D.G., Morey, R.V., De Kam, M.J., 2007. Economic of biomass gasification/ combustion at fuel ethanol plants. ASABE Paper No. 076233, ASABE, St. Joseph, Mich.

Turton, R., Bailie, R.C., Whiting, W.B., Shaeiwitz, J.A., 2002. Analysis, Synthesis, and Design of Chemical Processes, second ed. Prentice Hall PTR.

Wang, L., Kumar, A., Weller, C.L., Hanna, M.A., Jones, D.D., 2009 Thermal degradation kinetics of distillers grains in nitrogen and air. Energy Sources, Part A: Recovery, Utilization, and Environmental Effects 31 (10), 797-806.

Wei, L., Pordesimo, L.O., Herndon, C.W., Batchelor, W.D., 2008. Cost analysis of micro-scale biomass gasification facilities through mathematical modeling. ASABE Paper No. 084424, ASABE, St. Joseph, Mich.

Wu, C.Z., Huang, H., Zheng, S.P., Yin, X.L., 2002. An economical analysis of biomass gasification and power generation in China. Bioresource Technology 83, 65-70.

Wu, C., Yin, X., Ma, L., Zhou, Z., Chen, H., 2008. Design and operation of a 5.5 MWe biomass integrated gasification combined cycle demonstration plant. Biomass and Bioenergy 22, 4259-4264.

Xinag, W., Wang, S., 2008. Investigation of gasification chemical looping combustion combined cycle performance. Energy and Fuels 22, 961-966. 